\title{
Fatty acid intake alters growth and immunity in milk-fed calves
}

\author{
T. M. Hill, ${ }^{* 1}$ M. J. VandeHaar,† L. M. Sordillo,‡ D. R. Catherman,§ H. G. Bateman II, ${ }^{*}$ and R. L. Schlotterbeck* \\ *Nurture Research Center, Provimi North America, Lewisburg, OH 45338 \\ †Department of Animal Science, and \\ ‡Department of Large Animal Clinical Sciences, Michigan State University, East Lansing 48824 \\ $\S$ Strauss Feeds, Watertown, WI 53098
}

\section{ABSTRACT}

The aim of the present study was to determine the effect of supplementing milk replacer (MR) with NeoTec4 (Provimi North America, Brookville, OH), a commercially available blend of butyric acid, coconut oil, and flax oil, on calf growth, efficiency, and indices of immune function. In trial 1a, 48 male Holstein calves were fed either a control MR that contained only animal fat or the same MR with NeoTec4 (treatment) along with free-choice starter. The MR $(28.7 \%$ crude protein, $15.6 \%$ fat) was fed at an average of $1 \mathrm{~kg}$ of dry matter $(\mathrm{DM}) / \mathrm{d}$. In trial $1 \mathrm{~b}$, weaned calves from trial 1a were all fed dry starter for $28 \mathrm{~d}$ without NeoTec4 (phase 1), and then half the calves were fed NeoTec4 for $28 \mathrm{~d}$ (phase 2). In trial 2, 40 male Holstein calves were fed a control MR with lard, coconut oil, and soy lecithin or the same MR supplemented with NeoTec4 (treatment). The MR (22.8\% crude protein, $18.9 \%$ fat) was fed at an average of $1 \mathrm{~kg}$ of DM/d; no starter was fed. In trial 1a, NeoTec4 improved average daily gain, feed intake, and feed efficiency, reduced the number of days that calves experienced scours, and reduced the medical treatments for clostridium sickness. In trials $1 \mathrm{a}$ and 2, NeoTec4 altered the inflammatory response to vaccination with Pasteurella at 5 wk of age and to challenge with Salmonella toxin at less than 2 wk of age (fed NeoTec4 for $6 \mathrm{~d}$ ), as observed by reduced hyperthermia and hypophagia, and altered the tumor necrosis factor- $\alpha$ response. In addition, NeoTec4 enhanced the response in IL-4 and globular protein estimates postchallenge and enhanced titers for bovine viral diarrhea and respiratory parainfluenza-3. Postchallenge serum concentrations of albumin were lower and urea nitrogen concentrations were greater in control calves than in calves fed NeoTec4. In trial 1b, performance did not differ during the first $28 \mathrm{~d}$ when no calves received NeoTec4, but calves receiving NeoTec4 in the second $28 \mathrm{~d}$ had greater average daily gain and feed efficiency.

Received October 15, 2010.

Accepted April 8, 2011.

${ }^{1}$ Corresponding author: mhill@provimi-na.com
We conclude that supplementation of MR with NeoTec4 alters some immune and inflammatory responses, including increasing titers to bovine viral diarrhea and respiratory parainfluenza-3 vaccinations, reduces scours, reduces medical treatments for clostridium sickness, and improves growth rates and feed efficiency.

Key words: fatty acid, immunity, health, calf

\section{INTRODUCTION}

Fatty acids have functions in mammals beyond their role as sources of energy. For example, butyrate enhances the development of rumen papillae (Sander et al., 1959) and that of both villi and pancreas (Kato et al., 1989; Guilloteau et al., 2004, 2009). Some mediumchain and polyunsaturated fatty acids have antimicrobial and antiviral properties (Hristov et al., 2004).

Fatty acids are interrelated in their functions. Linoleic and linolenic acids, and the fatty acids that they elongate to, are components of phospholipid membranes and are an important part of tight junctions within epithelial barriers, including the intestine mentioned earlier relative to butyrate. They have proinflammatory (n-6 series) and inflammatory resolving (n-3 series) roles. Merchant et al. (2005) reported that the risk of pneumonia in men decreased with increasing linoleic acid intake. Similarly, Hu et al. (1999) reported less ischemic heart disease in women with increased linolenic acid intake. Intakes of eicosapentaenoic acid and docosahexaenoic acid, however, were not related to pneumonia. Metabolic functions have been limited and abnormal functions accentuated when the diet includes a high content of linoleic acid, possibly because diets high in linoleic acid have reduced synthesis of docosahexaenoic acid from linolenic acid (Liou et al., 2007).

Few studies with specific fatty acids have been conducted in neonatal calves. Kato et al. (1989) and Guilloteau et al. (2004, 2009) reported increased digestive enzyme secretions and weight gain when butyrate was fed to calves. Curtis et al. (2000) reported that fish oil reduced enzymes associated with cartilage loss, including a reduction in tumor necrosis factor- $\alpha$ ( $\mathbf{T N F} \boldsymbol{\alpha})$, in calves. Ballou and DePeters (2008) examined effects 
of supplementing milk replacer with fish oil and found little effect on calf health and growth. We previously reported improved growth when specific fatty acids or groups of fatty acids (butyrate, coconut oil, canola oil, flax oil, fish oil) in calf milk replacers (MR), and starter and grower diets were fed (Hill et al., 2007a, 2009). We have also reported that fatty acids or blends of fatty acids reduce scouring in neonatal calves. Similar results were reported in both MR and starter feeds (Hill et al., 2007c; Fokkink et al., 2009) when a commercialized blend of butyrate, coconut oil, and flax oil (NeoTec4 MR, Provimi North America, Brookville, $\mathrm{OH}$ ) was included in either MR or starter feeds.

Health of dairy calves is a major issue on US farms (USDA, 2007). Sickness rates from scouring and respiratory infections can be quite high, and measures of immunity transferred to the calf from colostrum intake are frequently low. We hypothesized that supplementation of MR with a commercial blend of butyrate, coconut oil, and flax oil would improve selected indices of immune function of young calves.

\section{MATERIALS AND METHODS}

The aim of the present research was to determine the effect of supplementing MR with a blend of butyrate, coconut oil, and flax oil on calf growth, efficiency, and indices of immune function when the calves were fed MR at a high rate of intake. Two trials were conducted. In the first, calves were from a single dairy farm and had a relatively high health status. In the second, calves were from multiple farms, underwent a long transport time to the nursery, and had a relatively low health status. Measures were made of various cytokines, other serum constituents, as well as calf ADG, feed intake, feed efficiency, and scouring.

\section{Trial 1a}

This trial compared a control MR formulated with only animal fat and a treatment MR formulated to contain 1\% NeoTec4 MR (blend of butyrate, coconut oil, and flax oil). Holstein bull calves (2 to $5 \mathrm{~d}$ of age, $\mathrm{n}$ $=48$ ) from a single dairy farm were transported $3.5 \mathrm{~h}$ to the Nurture Research Center (Lewisburg, $\mathrm{OH}$ ) and received at approximately $1100 \mathrm{~h}$. Calves were fed a nonmedicated MR without NeoTec4 for their first 2 feedings. At $1100 \mathrm{~h}$ on the day after arrival, the calves were weighed (initial BW), blood was sampled from the jugular vein, serum was harvested, and serum protein concentration was immediately measured using an optical refractometer (Atago U.S.A. Inc., Bellevue, WA). Serum was frozen for later assessment of antibody titers. Calves were cared for by acceptable practices as described in the Guide for the Care and Use of Agricultural Animals in Agricultural Research and Teaching (FASS, 1999). Calves were randomly assigned to treatment (d 0).

The control consisted of feeding a medicated MR (1.43 $\mathrm{g}$ of both neomycin sulfate and oxytetracycline per as-fed kilogram) for $14 \mathrm{~d}$ followed by a nonmedicated MR for $42 \mathrm{~d}$ (Table 1). These MR were formulated with all animal fat. The treatment consisted of feeding a nonmedicated MR formulated with mostly animal fat and $1 \%$ NeoTec4 MR. All MR contained $28.5 \%$ CP and $15 \%$ fat (Excelerate, Milk Specialties Global Animal Nutrition, Carpentersville, IL), and were fed at the same percentage (on an as-fed powder basis) of BW for $56 \mathrm{~d}$, readjusted weekly based on calf BW. During d 1 to 14 , both MR powders were fed at $1.5 \%$ of $\mathrm{BW}$, and, during d 15 to 49 , MR powders were fed at $2.0 \% \mathrm{BW}$ both divided into equal a.m. and p.m. feedings. During d 50 to 56 , MR were fed at $1.0 \%$ BW at only the a.m. feeding. The MR were reconstituted at the rate of 150 $\mathrm{g}$ of powder per $1 \mathrm{~L}$ of warm water. All calves were fed a common textured calf starter $(20 \% \mathrm{CP}$ on DM basis; $37 \%$ whole corn, $35 \%$ supplement pellet, $25 \%$ whole oats, 3\% molasses; supplement pellet contained $66 \%$ soybean meal, $22 \%$ wheat middlings, $9 \%$ minerals and vitamins, $3 \%$ molasses) and fresh water ad libitum.

The MR powders were sampled daily at the a.m. feeding and composited. Every second bag $(22.7 \mathrm{~kg}$ ) of starter feed was sampled and composited. Composites of feeds were analyzed (AOAC, 2000) for DM (oven method 930.15), ash (oven method 942.05), CP (Kjeldahl; method 988.05), fat (alkaline treatment with Röse-Gottlieb, method 932.06, for MR; diethyl ether extraction, method 2003.05, for starters and hay), fatty acids (GC; method 963.22), and Ca, P, K, and Mg (dry ashing, acid digestion, and analysis by inductively coupled plasma spectrometry, method 985.01). Additionally, the starter was analyzed for NDF with ash by the procedure of Van Soest et al. (1991) without sodium sulfite or $\alpha$-amylase, and ADF with ash (Robertson and Van Soest, 1981). Results are shown in Table 1.

Calves were weighed every $7 \mathrm{~d}$ until the end of the trial (d 56). Dry feed offered and feed refusals were weighed daily. Fecal scores were assigned daily based on a 1 to 5 system ( 1 being normal, thick in consistency; 2 being normal, but less thick; 3 being abnormally thin but not watery; 4 being watery; 5 being watery with abnormal coloring; modified from Kertz and ChesterJones, 2004). Hip widths were measured with a caliper, and BCS of calves were measured during the initial (d 0 ) measurement period and every $14 \mathrm{~d}$ thereafter. A 1 to 5 system using 0.25 -unit increments, with 1 being emaciated and 5 being obese, was used for BCS (Wildman et al., 1982). Scores were based on changes around 
Table 1. Nutrient concentrations (DM basis) of the feeds from all trials ${ }^{1}$

\begin{tabular}{|c|c|c|c|c|c|c|c|}
\hline \multirow[b]{2}{*}{ Item } & \multicolumn{3}{|c|}{ Trial $1 \mathrm{a}$, d 0 to 56} & \multirow{2}{*}{$\begin{array}{c}\text { Trial } 1 \mathrm{a}, 1 \mathrm{~b}, \\
\text { d } 56 \text { to } 84 \\
\\
\text { Starter } \\
- \text { NeoTec } 4\end{array}$} & \multicolumn{2}{|c|}{ Trial 1b, d 84 to 112} & \multirow{2}{*}{$\begin{array}{c}\text { Trial } 2 \\
\text { MR }\end{array}$} \\
\hline & $\begin{array}{c}\text { MR } \\
\text { nonmedicated } \\
- \text { NeoTec4 }\end{array}$ & $\begin{array}{c}\text { MR } \\
\text { medicated } \\
- \text { NeoTec4 }\end{array}$ & $\begin{array}{c}\text { MR } \\
\text { nonmedicated } \\
+ \text { NeoTec4 }\end{array}$ & & $\begin{array}{c}\text { Starter + } \\
\text { NeoTec4 }\end{array}$ & Hay & \\
\hline \multicolumn{8}{|l|}{ Analyzed, \% } \\
\hline $\mathrm{DM}$ & 96.4 & 96.4 & 96.5 & 87.1 & 87.0 & 88.5 & 96.9 \\
\hline $\mathrm{NDF}$ & ND & ND & ND & 12.2 & 12.3 & 51.3 & ND \\
\hline ME, Mcal/kg & 4.09 & 4.04 & 4.06 & 3.32 & 3.32 & 2.41 & 4.10 \\
\hline \multicolumn{8}{|l|}{ Fatty acid, $\%$} \\
\hline $\mathrm{C} 4$ & 0.057 & 0.021 & 0.452 & 0.018 & 0.298 & 0.004 & 0.069 \\
\hline C10 & 0.005 & 0.009 & 0.066 & 0.008 & 0.039 & 0.005 & 0.191 \\
\hline $\mathrm{C} 12$ & 0.038 & 0.034 & 0.533 & 0.021 & 0.291 & 0.004 & 1.589 \\
\hline
\end{tabular}

${ }^{1} \mathrm{MR}=$ milk replacer; NeoTec4 was from Provimi North America (Brookville, OH).

${ }^{2} \mathrm{ND}=$ not determined

the vertical and transverse processes of the spine as palpated by one experienced technician and ranged from 1.5 to 3.5. The trial lasted $56 \mathrm{~d}$ and was conducted during the months of January through March. The average ambient temperature inside the barn during the trial was $12^{\circ} \mathrm{C}$ and ranged from -5 to $29^{\circ} \mathrm{C}$ based on hourly measurements.

Calves were housed in 1.2 - by $2.4-\mathrm{m}$ individual pens within a curtain sidewall barn with no added heat. The pens were bedded with long straw. Calves received an intranasal tissue-sensitive respiratory disease vaccine (TSV-2, Pfizer, Exton, PA) and subcutaneous injections of vitamins A, D, E (Vital E - A + D, ScheringPlough Animal Health, Union, NJ) and Se (MU-SE, Schering-Plough Animal Health) upon arrival. Calves received an intramuscular respiratory disease vaccine (Bovashield Gold 5, Pfizer) at d 7 and again at d 28. At d 14 and 49 calves received an intramuscular vaccine for types C and D Clostridium (Vision 7 with Spur, Intervet Inc., Millsboro, DE) and a subcutaneous Clostridium perfringens type A toxoid (Novartis, Larchwood, IA). A Pasteurella vaccine (Presponse HM, Fort Dodge, Fort Dodge, IA) was administered intramuscularly on d 35 and 49. Calves were castrated and dehorned at $39 \mathrm{~d}$ of age. Calves with scours (fecal scores $>2$ ) were treated with oral electrolytes. Antibiotics were not used because the major historical causes of scours in this unit were rotavirus or Cryptosporidium parvum. Additionally, the duration of scours in this trial was short and antibiotics did not appear necessary. Calves that experienced abomasal bloat, abdominal colic, or had fecal samples positive for Clostridium perfringens combination type
A, B, C, D using lateral immunochromatography strips (Biox Diagnostics, Jemelle, Belgium) received $10 \mathrm{~mL}$ of Agri-Cillin (AgriLabs, St. Joseph, MO) orally and an intramuscular injection of Clostridium perfringens C\&D antitoxin (Colorado Serum Co., Denver, CO) as advised by a veterinarian. No calves were treated for other reasons or received other health-related products.

Subsets of 10 calves per treatment were randomly selected for additional measurements. On d 35 at 0800 $\mathrm{h}$, rectal temperature was measured, 2 samples of venous blood samples were collected (with and without EDTA), and the calf was vaccinated for pasteurella. At $3 \mathrm{~h}$ ( $\pm 5 \mathrm{~min})$ postvaccination, venous blood was again sampled with and without EDTA. Rectal temperature of each calf was measured again at 3,6 , and $24 \mathrm{~h}( \pm 5$ min) postvaccination. On d 49 and 56 , venous blood was sampled without EDTA at $0800 \mathrm{~h}$. Blood samples with EDTA were placed immediately on ice and sent (overnight) to Michigan State University (East Lansing) for analysis of cytokine transcript expression using quantitative real-time PCR (qPCR). Blood samples without EDTA from d 35 were allowed to clot; then, serum was separated by centrifugation, and analyzed for albumin, alkaline phosphatase, amylase, creatinine, glucose, total protein, and urea-N (globular protein was estimated as total protein minus albumin), as described in Hill et al. (2007a). Blood samples collected without preservative on d 49 and 56 were allowed to clot; then, serum was separated by centrifugation, frozen $\left(-20^{\circ} \mathrm{C}\right)$, and stored. Serum samples from d 0, 49, and 56 were analyzed for titers to bovine respiratory parainfluenza-3 (PI3) and bovine virus diarrhea type 1 (BVD) 
by The Ohio State University Diagnostic Laboratory (Reynoldsburg).

\section{RNA and Real-Time qPCR}

Total RNA was isolated from whole blood using the QIAamp RNA Blood Mini Kit (Qiagen, Valenica, $\mathrm{CA}$ ). To remove genomic DNA, a DNase digest was performed on the RNA using the RNase-Free DNase Set (Qiagen) during the isolation and purification process. Concentration and purity of RNA were assessed using a NanoDrop 1000 spectrophotometer (Thermo Scientific, Waltham, MA); only samples having a 260 $\mathrm{nm} / 280 \mathrm{~nm}$ ratio of absorbance between 1.95 and 2.1 were used (6 samples were excluded in trial 2). The paired pre- or postvaccination sample was also deleted, resulting in the loss of 2 calves per treatment.). Then, cDNA was synthesized using the High Capacity cDNA Reverse Transcriptase Kit with RNase inhibitor (Applied Biosystems, Foster City, CA). All of the primers used in the present study were derived from the Bos taurus genome (GenBank) and were designed by Applied Biosystems. The commercially available expression assays included IL-10 (Bt03212727_m1), IL-4 (Bt03211897_m1), IL-6 (Bt03211905_m1), TNFo (Bt03259154_m1), and $\beta$-actin (Bt03279174_gl). Realtime qPCR was carried out on a 7500 Fast Real-Time PCR system (Applied Biosystems) using the expressions assays. The qPCR was performed in triplicate using a $10-\mu \mathrm{L}$ reaction mixture per well, containing 5 $\mu \mathrm{L}$ of TaqMan Fast Universal PCR Master Mix $(2 \times$, Applied Biosystems), 0.5 $\mu \mathrm{L}$ of $(20 \times)$ TaqMan Gene Expression Assay Mix (Applied Biosystems), $22 \mathrm{ng}$ of cDNA, with the balance made up with nuclease-free water. A $(20 \times)$ Taqman Gene Expression Assay Mix for bovine $\beta$-actin by Applied Biosystems was used as the reference gene. The following thermal cycling conditions for fast 2-step PCR were used: stage 1 enzyme activation, $95^{\circ} \mathrm{C}$ for $20 \mathrm{~s}$; stage $2,95^{\circ} \mathrm{C}$ for $3 \mathrm{~s}$; stage $3,60^{\circ} \mathrm{C}$ for $30 \mathrm{~s}$; with 40 replications through stages 2 and 3. Quantification was carried out with the relative quantification method (Livak and Schmittgen, 2001). The abundance of target genes, normalized to average of the reference gene and relative to a calibrator are presented as $2^{-\Delta \Delta \mathrm{Ct}}$, where $C_{t}$ is the cycle number at which the fluorescence signal of the product crosses an arbitrary threshold set with exponential phase of the $\mathrm{PCR}$, and $\Delta \Delta \mathrm{Ct}=\left(\mathrm{Ct}_{\text {target gene Unk }}-\mathrm{Ct}\right.$ reference gene Unk sample $)-\left(\mathrm{Ct}_{\text {target gene Cal }}-\mathrm{Ct}\right.$ reference gene Cal $)$, where Unk $=$ unknown and $\mathrm{Cal}=$ calibrator. Averaged abundance of target genes of the prevaccinated control group was considered the calibrator.

Growth data were analyzed using the MIXED procedure in SAS (version 8, SAS Institute Inc., Cary,
$\mathrm{NC}$ ) as a completely randomized design. The statistical model used was

$$
\mathrm{Y}_{\mathrm{ijkl}}=\mu+\mathrm{T}_{\mathrm{i}}+\mathrm{w}_{\mathrm{j}}+\mathrm{Tw}_{\mathrm{ij}}+\mathrm{C}_{\mathrm{k}}\left(\mathrm{T}_{\mathrm{i}}\right)+\varepsilon_{\mathrm{ijk} \mathrm{l}},
$$

where $Y_{\mathrm{ijkl}}$ is the observed measurement, $\mu$ represents the overall population mean, $\mathrm{T}_{\mathrm{i}}$ is the fixed effect of treatment $i, w_{j}$ is the random effect of week $j, T_{w_{i j}}$ is the interaction of treatment $i$ and week $j, C_{k}\left(T_{i}\right)$ is the random effect of calf $\mathrm{k}$ nested within treatment $\mathrm{i}$ that was used to test the effect of treatment, and $\varepsilon_{\mathrm{ijkl}}$ is the residual assumed to be normally distributed with mean zero. Week was modeled as a repeated measurement using an autoregressive type 1 covariance structure.

Data of cytokine measurements from mononuclear cells and serum samples collected on d 35 were analyzed by period (prevaccinated sample, postvaccinated sample, and the change between samples) as raw values before converting to $2^{-\Delta \Delta \mathrm{Ct}}$ form using prevaccinated calves without NeoTec4 as the reference point for reporting. For these data the statistical model used was

$$
\mathrm{Y}_{\mathrm{ij}}=\mu+\mathrm{T}_{\mathrm{i}}+\varepsilon_{\mathrm{ij}}
$$

where $Y_{\mathrm{ij}}$ is the observed measurement, $\mu$ is the overall population mean, $T_{i}$ is the fixed effect of treatment $i$, and $\varepsilon_{\mathrm{ij}}$ is the random residual assumed normally distributed with mean zero.

Serum titer measurements were transformed to log 2 values and were analyzed on d 49 and 56 using d 0 titers as a covariate. For these data the statistical model used was

$$
\mathrm{Y}_{\mathrm{ikj}}=\mu+\mathrm{C}_{\mathrm{i}}+\mathrm{T}_{\mathrm{j}}+\varepsilon_{\mathrm{ijk}},
$$

where $Y_{i k j}$ is the observed measurement, $\mu$ represents the overall population mean, $\mathrm{C}_{\mathrm{i}}$ is the fixed effect of covariate measurement $i, T_{j}$ is the fixed effect of treatment $\mathrm{j}$, and $\varepsilon_{\mathrm{ijk}}$ is the random residual assumed to be normally distributed with mean zero.

Wilcoxon rank sum tests (PROC NPAR1WAY function) were used to analyze medical treatments. All data are reported as least squares means. The experimental unit was calf. Statistical significant differences are discussed at $P<0.05$, and trends are mentioned when $P$ $<0.10$.

\section{Trial $1 b$}

To assess the effect of NeoTec4 in MR on subsequent growth postweaning, calves from trial 1a were moved to multi-calf pens on d 56, with calves grouped 4 per pen by MR treatment. Trial $1 \mathrm{~b}$ was conducted in 2 phases. During phase 1 (from 56 to 84 d), all calves 
were fed the same starter as used in trial 1a blended with $5 \%$ chopped grass hay before feeding. Treatments were calves not fed NeoTec4 in MR (control) and calves fed NeoTec4 in MR during d 1 to 56 (treatment). During phase 2 (from 85 to $112 \mathrm{~d}$ ), calves remained in the same pens, but pens were reassigned to receive the same starter without NeoTec4 or a new starter containing 0.5\% NeoTec4 10 (Provimi North America; a proprietary blend of fatty acids based on published research; Hill et al., 2007c) creating 4 treatments, as follows: $\mathrm{A}=$ no NeoTec4 in previous MR, no NeoTec4 in starter; $\mathrm{B}=$ no NeoTec4 in previous MR, NeoTec4 in starter; $\mathrm{C}=$ NeoTec4 in previous MR, no NeoTec4 in starter; and $\mathrm{D}=$ NeoTec4 in previous MR, NeoTec4 in starter. The NeoTec4 was formulated as a portion of the protein supplement pellet. Ingredient composition of the starter pellets is presented in Table 1.

Pens had $6.5 \mathrm{~m}^{2}$ of outside space and $1.35 \mathrm{~m}^{2}$ of inside space per calf. The inside space was bedded with long straw and there was no added heat. No animals were sick or were treated for sicknesses or vaccinated during the 56-d trial. Calves were weighed, hip widths were measured, and body condition was scored initially and every 28 d. Feed offered and refused was weighed daily. Hip widths were measured with a caliper. Calf BCS was based on a 1 to 5 system as described earlier. Pens had 4 calves each and pen was the experimental unit.

Data from the 2 phases of trial $1 \mathrm{~b}$ were analyzed separately using the MIXED procedure of SAS (version 8, SAS Institute Inc.). Data from each phase was analyzed using the following model:

$$
\mathrm{Y}_{\mathrm{ij}}=\mu+\mathrm{T}_{\mathrm{i}}+\varepsilon_{\mathrm{ij}},
$$

where $Y_{i j}$ is the observed measurement, $\mu$ represents the overall population mean, $T_{j}$ is the fixed effect of treatment $\mathrm{j}$, and $\varepsilon_{\mathrm{ij}}$ is the random residual assumed to be normally distributed with mean zero. Because data analysis for trial $1 \mathrm{~b}$ were conducted on rate of change (e.g., ADG, change in body size and composition), final measures from trial 1a were not used as covariates during analysis of the data in phase 1 nor were final measures from phase 1 used as covariates for analysis of data in phase 2 . Treatment means were considered statistically different at $P<0.05$ and a statistical trend at $P<0.10$.

\section{Trial 2}

This trial examined effects of supplementing NeoTec4 in a commercial veal MR that was $23.0 \% \mathrm{CP}$ and $18.5 \%$ fat (DM basis) and contained a blend of fats $(28 \%$ coconut oil, $7 \%$ soy lecithin, $1 \%$ emulsifier, and the balance added as animal fat). Holstein bull calves $(\mathrm{n}=40)$ that were less than $7 \mathrm{~d}$ of age were obtained from multiple dairy farms and received at the research nursery at approximately $0700 \mathrm{~h}$ after a 15 -h transit. Calves were randomly assigned to 1 of 2 treatments (control or treatment; d 0). Calves received an intramuscular Salmonella typhimurium bacterin toxiod (Endovac-Porci, IMMVAC Inc., Columbia, MO) on d 6. Calves received an intramuscular respiratory disease vaccine (Pyramid 5, Fort Dodge Animal Health) at d 2 and again at $\mathrm{d} 15$.

The MR powders were blended and fed at an increasing concentration and rate with time, starting at 0.33 $\mathrm{kg}$ of $\mathrm{DM} / \mathrm{d}$ and increasing to $1.68 \mathrm{~kg}$ of $\mathrm{DM} / \mathrm{d}$ by d 45 to average $1.0 \mathrm{~kg} / \mathrm{d}$. The dilution of the powder with water began at $107 \mathrm{~g} / \mathrm{L}$ and increased to $161 \mathrm{~g}$ of as-fed powder/L volume. Enough MR powder was reconstituted with water and mixed for all calves, and then calves assigned to the control were fed. Immediately following this, NeoTec4 MR powder (Provimi North America) was added to the reconstituted MR liquid at the rate of $7 \mathrm{~g} /$ calf daily and fed to calves assigned to treatment. The added NeoTec4 increased the concentration of solids in the MR by approximately $3.4 \mathrm{~g} / \mathrm{L}$. Calves were fed their daily allotment of MR in 2 equal allotments at 1130 and $2330 \mathrm{~h}$.

Calves were fed their first MR at $1130 \mathrm{~h}$ on the day of arrival. At $1000 \mathrm{~h}$ on the day of arrival, $1300 \mathrm{~h}$ on the day after arrival, and $1000 \mathrm{~h}$ on d 39, 41, and 45, blood was sampled from the jugular vein. Serum was harvested from samples collected on the day of and day after arrival were immediately measured for serum protein using an optical refractometer (Atago U.S.A. Inc.). Serum harvested from samples taken on d 0, 39, and 45 were frozen for the titer assays described earlier. On d 6, a subset of 10 calves per treatment was randomly selected for additional measurements. At $0800 \mathrm{~h}$, venous blood samples were collected with and without EDTA, and then the calf was immediately vaccinated with Salmonella typhimurium bacterin toxoid. At $2.5 \mathrm{~h}( \pm 5 \mathrm{~min})$ postvaccination, venous blood was sampled again.

Serum from d 6 was analyzed for various constituents as well as titers to PI3 and BVD, as described for trial 1a. Blood samples collected with EDTA were immediately placed on ice upon sampling and stored for processing 24 to $36 \mathrm{~h}$ later at Michigan State University (East Lansing) for qPCR analyses of cytokine relative mRNA abundance as described for trial 1a. Statistical analyses of cytokine mRNA abundance and serum constituent data were as described for trial 1a. 


\section{RESULTS}

\section{Trial 1a}

Analyses of the diets are shown in Table 1 . The treatment MR contained approximately 7 times the concentration of butyrate, 7 times the concentration of medium-chain fatty acids, and 2 times the concentration of linolenic acid as the control MR. Initial measurements did not differ $(P>0.05$; Table 2$)$. Milk replacer offered was completely consumed, except for some calves rejecting MR for $4 \mathrm{~d}$ after Pasteurella vaccination on d 35 . On d 35 to 38 , MR intake was less $(P<0.05)$ for calves fed the control (Figure 1) because more calves showed incomplete consumption of milk when fed the control during d 35 to 38 compared with calves fed the treatment. Milk replacer intake did not differ $(P$ $>0.05)$ as a percentage of BW between the control and treatment calves (Table 2). Starter intake did not differ $(P>0.05)$. Intake of butyrate, the medium-chain fatty acids, and linolenic acid was greater $(P<0.001)$ in calves fed the treatment compared with those fed the control. A MR by week interaction $(P<0.05)$ was observed for ADG: calves fed the treatment had a greater $(P<0.05)$ ADG for wk 5,6 , and 7 compared with calves fed the control. Over the 56-d trial, calf ADG was $10 \%$ greater $(P<0.05)$ for calves fed the treatment compared with those fed the control. Feed efficiency tended $(P<0.10)$ to be $6 \%$ greater for calves fed the treatment compared with those fed the control. Hip width change tended to be greater $(P<0.06)$ for calves fed the treatment compared with those fed the control. No antibiotic treatments were used for scouring; however, medical doses were all from electrolytes. These were during the first $28 \mathrm{~d}$ of the trial. During the last $28 \mathrm{~d}$ of the trial, bloating calves were treated with $10 \mathrm{~mL}$ of penicillin orally and with $\mathrm{C} \& \mathrm{D}$ antitoxin for C. perfringens. All medical treatments during last $28 \mathrm{~d}$ were this combination (considered one medical treatment) and were greater $(P<0.04)$ in calves in the control group compared with those in the treatment group (Figure 2). Over $56 \mathrm{~d}$, medical treatment days tended to be less $(P<0.06$; Figure 2$)$ for calves fed the treatment compared with the control. Over $56 \mathrm{~d}$, abnormal fecal score days were fewer $(P<0.05)$ for calves fed the treatment compared with the control. Average fecal score tended to be less $(P<0.09)$ for calves fed the treatment compared with the control.

Overall, the transcript abundance of the proinflammatory cytokine TNFa in whole blood samples did not

Table 2. Performance of calves from 0 to $56 \mathrm{~d}$ fed milk replacers (MR) with and without NeoTec4 fatty acids (Provimi North America, Brookville, $\mathrm{OH})$ in trial 1a

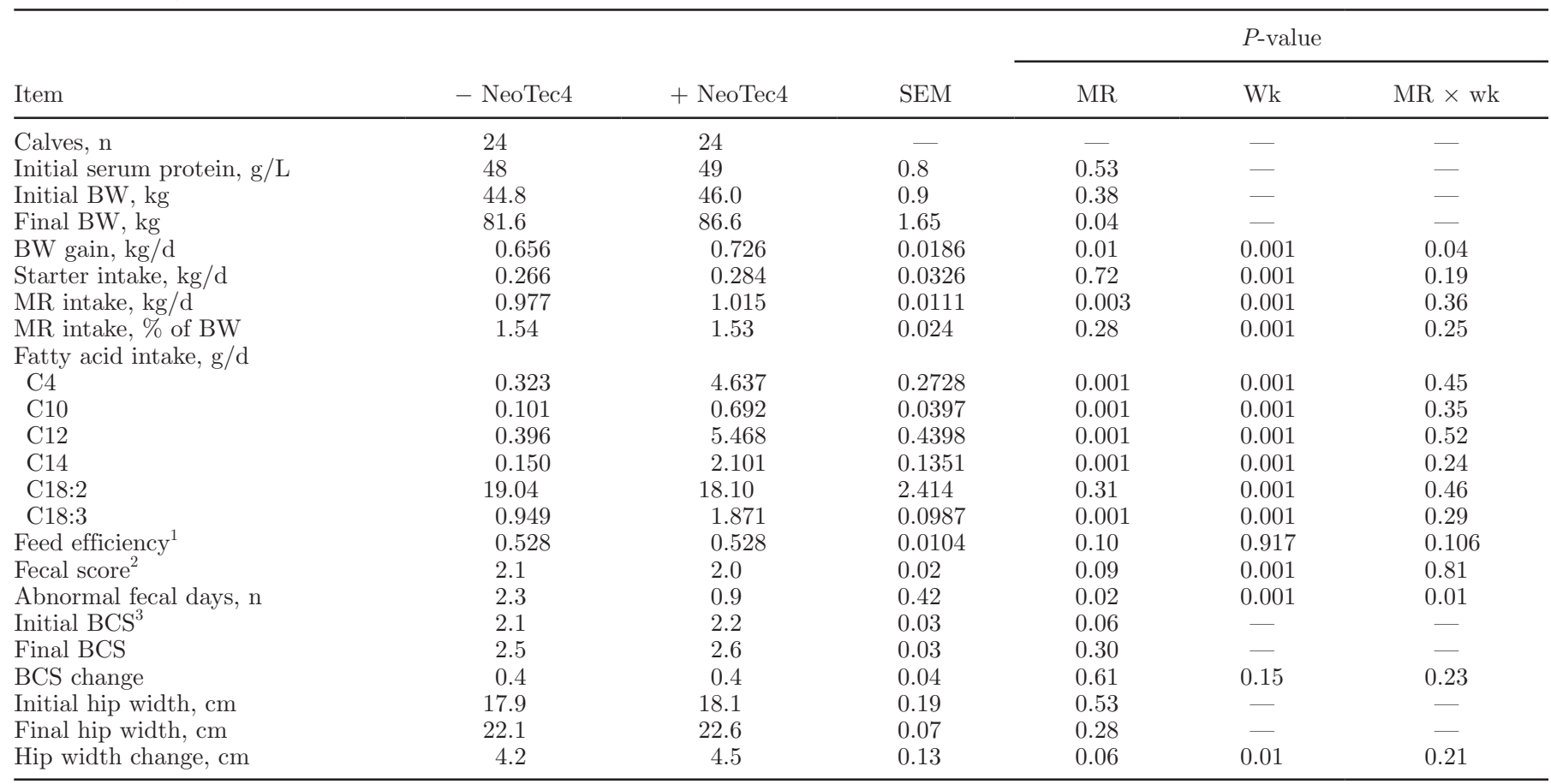

${ }^{1}$ Gain divided by milk replacer plus starter intake.

${ }^{2}$ Where $1=$ normal, thick in consistency; $2=$ normal, but less thick; $3=$ abnormally thin but not watery; $4=$ watery; $5=$ watery with abnormal coloring.

${ }^{3}$ BCS: 1 to 5 system based on Wildman et al. (1982). 


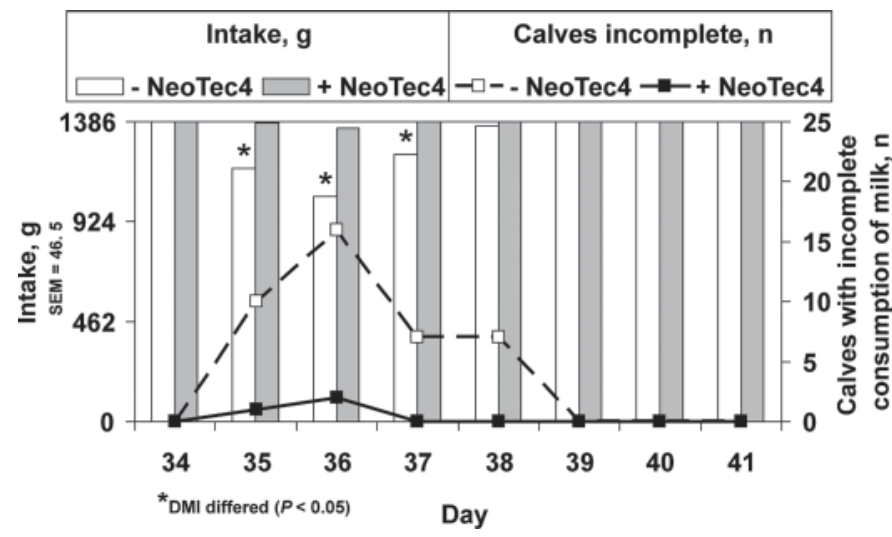

Figure 1. Daily milk replacer intake per calf and number of calves with incomplete consumption of milk replacer by day for d 34 (day of Pasteurella vaccination) to 41 for calves fed milk replacers with and without NeoTec4 fatty acids (Provimi North America, Brookville, $\mathrm{OH}$ ) in trial 1a.

change from pre- to postvaccination with pasteurella vaccine on d 36 (Table 3). However, the change due to vaccination differed for the treatments $(P<0.04)$, with TNFa mRNA increasing in control calves but decreasing in calves in the treatment group (Table 3). Consistent with this, the increase in rectal temperature and the number of calves rejecting some of their MR fed (lethargy) postvaccination also was less $(P<0.03)$ in calves fed the treatment compared with those fed the control (Table 3). Additionally, the change from pre- to postvaccination for IL- 4 mRNA abundance tended $(P$ $=0.09)$ to differ between MR treatment groups, with IL-4 apparently increasing in calves fed the treatment, but decreasing in control calves. Pre- and postvaccina- tion changes in IL-6 and IL-10 did not differ by MR treatments.

Pre- and postvaccination serum concentrations of alkaline phosphatase and amylase were greater $(P<$ 0.05 ) in calves fed the treatment (Table 4). Prevaccination serum concentrations of total protein and albumin tended $(P<0.10)$ to be greater in calves fed the treatment. Postvaccination concentrations of total protein and albumin and the change in concentrations from prevaccination measures were greater $(P<0.05)$ in calves fed the treatment. The globular protein estimate increased more $(P<0.01)$ postvaccination in calves fed the treatment compared with control. In addition, postbooster vaccine titers to PI3 and BVD were greater $(P<0.05)$ in calves fed the treatment (Table 5$)$.

\section{Trial $1 b$}

Analyses of the diets are shown in Table 1. The treatment starter contained approximately 16 times the concentration of butyrate, 12 times the concentration of medium-chain fatty acids, and 2 times the concentration of linolenic acid as the control starter. Results for d 56 to 84 (phase 1) are shown in Table 6. Only the control starter was fed during this phase. Calves previously fed the control MR consumed more DM as a percentage of BW $(2.65$ vs. $2.34 \% ; P<0.01)$ and tended to consume more DM $(2.49$ vs. $2.32 \mathrm{~kg} / \mathrm{d} ; P$ $<0.07)$ than calves previously fed the treatment MR. Other measurements were not different.

Results for 84 to $112 \mathrm{~d}$ (phase 2) are shown in Table 7. Calves fed the treatment had $9 \%$ greater $(P<0.05)$ ADG and $7 \%$ greater $(P<0.05)$ feed efficiency than

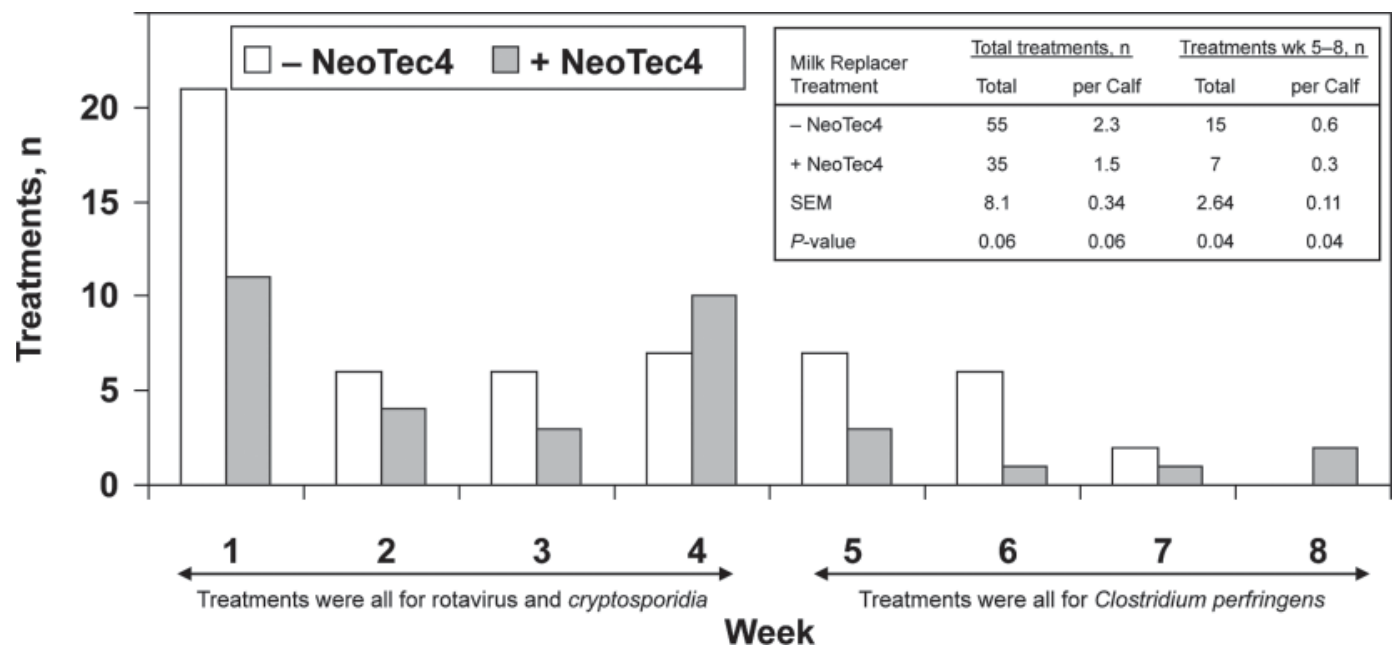

Figure 2. Medical treatments by week for the 24 calves fed a milk replacer without NeoTec4 fatty acids (Provimi North America, Brookville, $\mathrm{OH})$ and the 24 calves fed a milk replacer with NeoTec4 fatty acids in trial 1a. Disease cause appeared different between the first and second half of the trial. 
Table 3. Relative mRNA abundance of proinflammatory cytokines ${ }^{1}$ pre- and postvaccination and change and the body temperature of calves relative to vaccination in calves fed milk replacers with and without NeoTec4 fatty acids (Provimi North America, Brookville, OH) in trial 1a

\begin{tabular}{|c|c|c|c|c|}
\hline Item & - NeoTec4 & + NeoTec4 & SEM & $P$-value \\
\hline \multicolumn{5}{|l|}{ Tumor necrosis factor- $\alpha$} \\
\hline Prevaccination & 1.02 & 1.11 & 0.178 & 0.98 \\
\hline Postvaccination & 1.31 & 0.89 & 0.236 & 0.12 \\
\hline Change & 0.29 & -0.22 & 0.190 & 0.04 \\
\hline \multicolumn{5}{|l|}{ IL-4 } \\
\hline Prevaccination & 1.49 & 1.66 & 0.562 & 0.82 \\
\hline Postvaccination & 0.78 & 2.46 & 0.566 & 0.46 \\
\hline Change & -0.71 & 0.80 & 0.631 & 0.09 \\
\hline \multicolumn{5}{|l|}{ IL-6 } \\
\hline Prevaccination & 1.23 & 1.26 & 0.434 & 0.59 \\
\hline Postvaccination & 1.98 & 1.92 & 0.497 & 0.62 \\
\hline Change & 0.75 & 0.66 & 0.291 & 0.96 \\
\hline \multicolumn{5}{|l|}{ IL-10 } \\
\hline Prevaccination & 1.37 & 2.21 & 0.524 & 0.71 \\
\hline Postvaccination & 0.71 & 0.75 & 0.299 & 0.91 \\
\hline Change & 0.66 & 0.46 & 0.425 & 0.70 \\
\hline \multicolumn{5}{|l|}{ Rectal temperature,${ }^{2} \mathrm{C}$} \\
\hline $0 \mathrm{~h}$ (prevaccination) & 38.57 & 38.57 & 0.134 & 0.78 \\
\hline $3 \mathrm{~h}$ postvaccination & 38.92 & 38.58 & 0.187 & 0.13 \\
\hline $6 \mathrm{~h}$ postvaccination & 39.28 & 38.81 & 0.104 & 0.03 \\
\hline $24 \mathrm{~h}$ postvaccination & 39.01 & 38.58 & 0.028 & 0.01 \\
\hline Mean & 38.93 & 38.64 & 0.008 & 0.01 \\
\hline
\end{tabular}

${ }^{1}$ Data are reported in $2^{-\Delta \Delta \mathrm{Ct}}$ form with prevaccinated calves without NeoTec4 as the reference expression point.

${ }^{2}$ Time was significant $(P<0.01)$ but time $\times$ treatment was not $(P>0.10)$.

Table 4. Serum constituents pre- and postvaccination and change in calves fed milk replacers with and without NeoTec4 fatty acids (Provimi North America, Brookville, $\mathrm{OH})$ in trial 1a

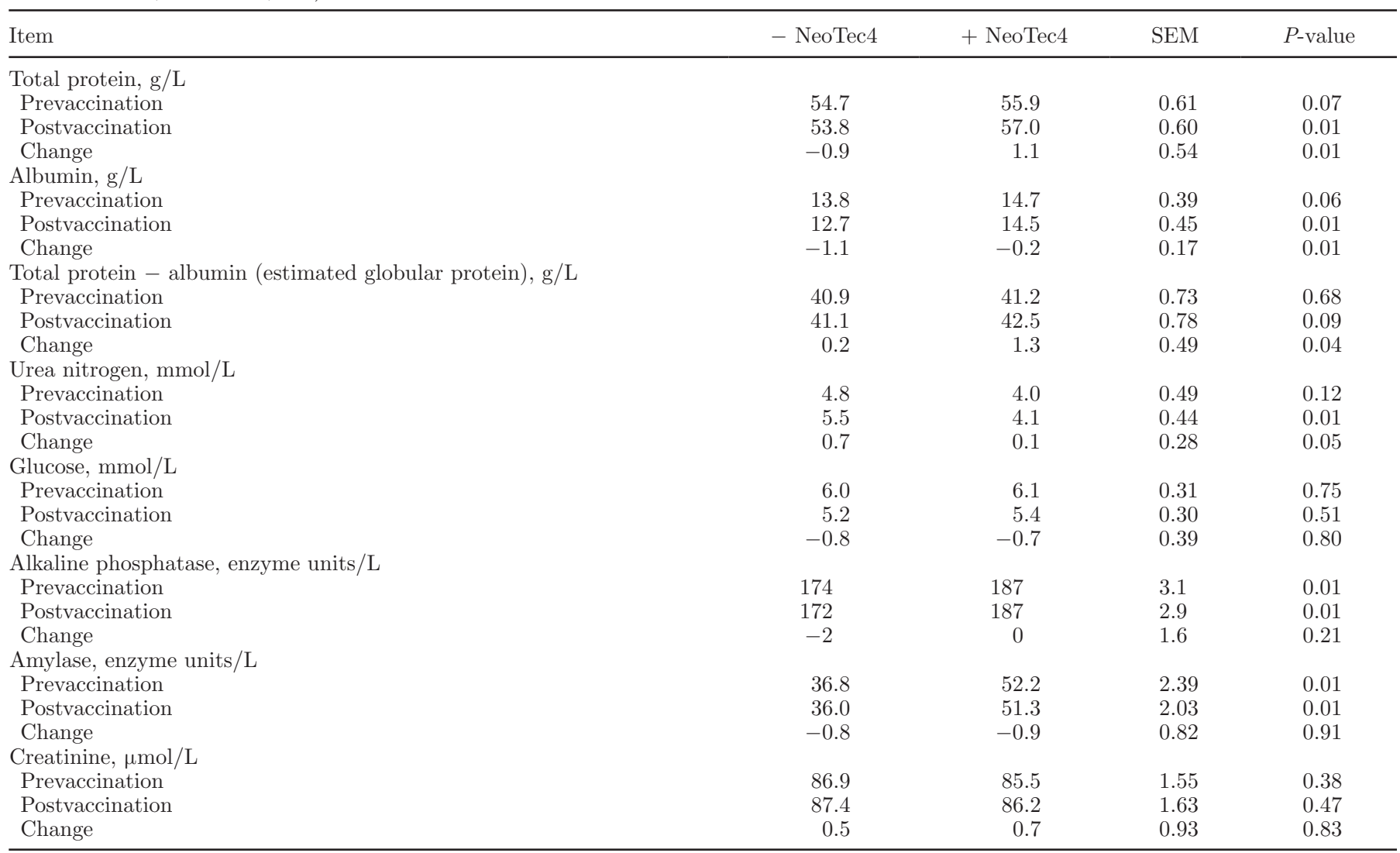


Table 5. Serum titers ( $\log 2)$ to respiratory parainfluenza-3 (PI3) and bovine virus diarrhea type 1 (BVD) determined using $\mathrm{d} 0$ titers before vaccination as a covariate in calves fed milk replacers with and without NeoTec4 fatty acids (Provimi North America, Brookville, OH) in trials 1a and 2

\begin{tabular}{lcccc}
\hline Item & - NeoTec4 & + NeoTec4 & SEM & $P$-value \\
\hline Trial 1a & & & & \\
BVD & 5.3 & 6.4 & 0.26 & 0.01 \\
PI3 & 6.0 & 6.9 & 0.23 & 0.03 \\
Trial 2 & & 7.8 & 0.34 & 0.09 \\
BVD & 6.9 & 7.7 & 0.16 & 0.02 \\
PI3 & 7.1 & & \\
\hline
\end{tabular}

calves fed the control, consistent with previous reports (Hill et al., 2007c). Other measures did not differ. The ADG and feed efficiency response to the treatment occurred during d 1 to 56 when the treatment was fed, and did not occur during d 56 to 84 when the treatment was not fed. The ADG and feed efficiency response reoccurred during d 84 to 112 when NeoTec4 was reinserted in the diet of half of the calves, further demonstrating the effectiveness of the fatty acids.

\section{Trial 2}

Analysis of the MR fed is shown in Table 1. NeoTec4 that was supplemented was $97.2 \% \mathrm{DM}, 56.1 \% \mathrm{CP}$, and $25.9 \%$ fat. Analyses were as expected. Initial concentrations of serum protein measured at 3 and $30 \mathrm{~h}$ did not differ $(P>0.05)$ between MR treatments (Table 8).
Serum protein concentrations appeared higher for the $3 \mathrm{~h}$ samples compared with $30 \mathrm{~h}$ samples. This likely reflected dehydration in the calves at $3 \mathrm{~h}$.

The change in mRNA abundance for both $\mathrm{TNF} \alpha$ and IL-4 in the mononuclear cells from pre- to postadministration with Salmonella toxoid on d 6 differed $(P<0.05)$ between calves fed the treatment and those fed the control MR (Table 9). In calves fed the treatment, TNFo appeared to decline and IL-4 appeared to increase in postadministration samples of calves fed the treatment, whereas $\mathrm{TNF} \alpha$ appeared to increase and IL-4 changed little in control calves. These results are consistent with those in trial 1a; however, in this trial the results were after only $6 \mathrm{~d}$ on the treatment compared with $35 \mathrm{~d}$ in trial 1a. The treatment had no effect on abundance of transcripts for IL-6 and IL-10 in trial 2 , as in trial $1 \mathrm{a}$.

Table 6. Performance of weaned calves fed a starter without NeoTec4 fatty acids (Provimi North America, Brookville, $\mathrm{OH}$ ) that had previously been fed milk replacers with and without NeoTec4 fatty acids in the first 28 -d period of trial $1 \mathrm{~b}$

\begin{tabular}{|c|c|c|c|c|}
\hline \multirow[b]{2}{*}{ Item } & \multicolumn{2}{|c|}{ Preweaning } & \multirow[b]{2}{*}{ SEM } & \multirow[b]{2}{*}{$P$-value } \\
\hline & - NeoTec & + NeoTec 4 & & \\
\hline Pens ( 4 calves/pen) & 6 & 6 & & \\
\hline Initial BW, $\mathrm{kg}$ & 81.6 & 86.8 & 2.40 & 0.062 \\
\hline Final BW, kg & 106.0 & 111.9 & 3.38 & 0.11 \\
\hline $\mathrm{ADG}, \mathrm{kg} / \mathrm{d}$ & 0.865 & 0.894 & 0.0690 & 0.69 \\
\hline DMI ${ }^{1} \mathrm{~kg} / \mathrm{d}$ & 2.49 & 2.32 & 0.084 & 0.07 \\
\hline DMI, $\%$ of BW & 2.65 & 2.34 & 0.071 & 0.01 \\
\hline \multicolumn{5}{|l|}{ Fatty acid intake, $\mathrm{g} / \mathrm{d}$} \\
\hline $\mathrm{C} 4$ & 0.431 & 0.401 & 0.0166 & 0.11 \\
\hline $\mathrm{C} 10$ & 0.195 & 0.182 & 0.0094 & 0.13 \\
\hline $\mathrm{C} 12$ & 0.502 & 0.467 & 0.0213 & 0.07 \\
\hline C14 & 0.268 & 0.249 & 0.0140 & 0.17 \\
\hline $\mathrm{C} 18: 2$ & 45.2 & 42.2 & 2.27 & 0.09 \\
\hline $\mathrm{C} 18: 3$ & 3.53 & 3.29 & 0.164 & 0.07 \\
\hline Feed efficiency $^{2}$ & 0.347 & 0.387 & 0.0327 & 0.25 \\
\hline Initial hip width, $\mathrm{cm}$ & 22.1 & 22.6 & 0.16 & 0.01 \\
\hline Final hip width, cm & 24.5 & 25.2 & 0.29 & 0.03 \\
\hline Hip width change, $\mathrm{cm}$ & 2.4 & 2.6 & 0.20 & 0.32 \\
\hline Initial $\mathrm{BCS}^{3}$ & 2.5 & 2.6 & 0.054 & 0.06 \\
\hline Final BCS & 2.6 & 2.6 & 0.05 & 0.18 \\
\hline BCS change & 0.1 & 0.0 & 0.08 & 0.69 \\
\hline
\end{tabular}

${ }^{1}$ Time was significant $(P<0.01)$ but time $\times$ treatment was not $(P>0.10)$.

${ }^{2}$ Gain divided by DMI.

${ }^{3}$ BCS: 1 to 5 system based on Wildman et al. (1982). 
Table 7. Performance of calves fed starters with and without NeoTec4 fatty acids (Provimi North America, Brookville, $\mathrm{OH}$ ) from 84 to $112 \mathrm{~d}$ in the second 28 -d period of trial $1 \mathrm{~b}$

\begin{tabular}{|c|c|c|c|c|c|c|}
\hline \multirow{3}{*}{$\frac{\text { Item }}{\text { NeoTec4 in starter }}$} & \multicolumn{4}{|c|}{ Preweaning } & \multirow{3}{*}{ SEM } & \multirow{2}{*}{$\begin{array}{c}\text { Starter } \\
\text { NeoTec4 } \\
P \text {-value }\end{array}$} \\
\hline & \multicolumn{2}{|c|}{ - NeoTec4 } & \multicolumn{2}{|c|}{+ NeoTec 4} & & \\
\hline & - & + & - & + & & \\
\hline Pens ( 4 calves/pen) & 3 & 3 & 3 & 3 & & \\
\hline $\mathrm{ADG}, \mathrm{kg} / \mathrm{d}$ & 1.14 & 1.22 & 1.15 & 1.29 & 0.029 & 0.01 \\
\hline Final BW, kg & 134.3 & 143.7 & 145.3 & 146.6 & 3.37 & 0.15 \\
\hline $\mathrm{DMI},{ }^{1} \mathrm{~kg} / \mathrm{d}$ & 3.98 & 4.22 & 4.02 & 3.91 & 0.127 & 0.59 \\
\hline DMI, \% BW & 3.36 & 3.34 & 3.12 & 3.04 & 0.11 & 0.68 \\
\hline \multicolumn{7}{|l|}{ Fatty acid intake, $\mathrm{g} / \mathrm{d}$} \\
\hline $\mathrm{C} 4$ & 0.69 & 11.96 & 0.70 & 11.08 & 0.183 & 0.001 \\
\hline $\mathrm{C} 10$ & 0.31 & 1.57 & 0.32 & 1.46 & 0.030 & 0.001 \\
\hline $\mathrm{C} 12$ & 0.80 & 11.67 & 0.81 & 10.82 & 0.193 & 0.001 \\
\hline C14 & 0.43 & 5.87 & 0.43 & 5.43 & 0.091 & 0.001 \\
\hline $\mathrm{C} 18: 2$ & 72.31 & 76.51 & 73.04 & 70.89 & 2.562 & 0.34 \\
\hline $\mathrm{C} 18: 3$ & 5.65 & 10.00 & 5.70 & 9.26 & 0.214 & 0.001 \\
\hline Feed efficiency ${ }^{2}$ & 0.286 & 0.288 & 0.286 & 0.330 & 0.0062 & 0.03 \\
\hline Hip width change, $\mathrm{cm}$ & 2.8 & 2.6 & 2.0 & 2.6 & 0.21 & 0.36 \\
\hline Final hip width, cm & 27.0 & 27.4 & 27.4 & 27.6 & 0.21 & 0.19 \\
\hline $\mathrm{BCS}^{3}$ & 0.2 & 0.1 & 0.1 & 0.2 & 0.07 & 0.88 \\
\hline Final BCS & 2.8 & 2.8 & 2.8 & 2.7 & 0.05 & 0.33 \\
\hline
\end{tabular}

${ }^{1}$ Time was significant $(P<0.01)$ but time $\times$ treatment was not $(P>0.10)$.

${ }^{2}$ Gain divided by DMI.

${ }^{3}$ BCS: 1 to 5 system based on Wildman et al. (1982).

Pre- and postvaccination serum concentrations of alkaline phosphatase were greater $(P<0.05)$ in calves fed the treatment, consistent with trial 1a (Table 8). However, amylase concentrations did not differ, unlike results from trial 1a. This inconsistency may be related to sampling time (d 6 in trial 2 vs. d 35 in trial 1a), thus age of calf, and no starter intake in trial 2. In this trial, amylase concentrations in the serum were about $10 \%$ of trial 1a concentrations. Prevaccination serum concentrations of total protein and albumin were not different. Postvaccination concentrations of total protein and albumin and the change in concentrations from prevaccination measures were greater $(P<0.05)$ in calves fed the treatment as in trial 1a. Total protein minus albumin, an estimate of globular protein, between pre- and postvaccination serum samples was greater $(P<0.05)$ in calves fed the treatment, as in trial 1a. Serum urea nitrogen increased $(P<0.05)$ in calves fed the control but did not change in calves fed the treatment in response to the salmonella toxoid. Postbooster vaccine titers to PI3 were greater $(P<$ $0.03)$ and BVD titers tended to be greater $(P<0.09)$ in calves fed the treatment (Table 5).

\section{DISCUSSION}

Our data from trial 1a support the idea that butyric and linolenic acids reduced the inflammatory response. The response in both $\mathrm{TNF} \alpha$ and rectal temperatures lead us to conclude that the fatty acids in the treat- ment lessen the inflammatory response. The pre- to postvaccination increase in serum urea nitrogen was less and the minimal change in albumin in calves fed the treatment compared with the control possibly indicate less catabolic events at the cell level during an inflammatory response to a vaccine. An increase in BUN was reported by Orr et al. (1988) to an infectious bovine rhinotracheitis-challenged feeder steer. Total protein and albumin are sometimes reported to decline in animals with disease from increased catabolism of protein, vascular leakage with increased vascular permeability, and changes in liver synthesis of protein (Kim et al., 2003; Orhue et al., 2005; Merck Veterinary Manual, 2008).

Our results show for the first time that supplementation of MR to calves with a blend of butyric acid, coconut oil, and flax oil increased antibody responses and altered immune and inflammatory responses. Growth and feed efficiency were improved and scours were reduced by this fatty acid blend, as seen in previous studies (Hill et al., 2007a,b; Fokkink et al., 2009). Medical treatments for a natural clostridium sickness were reduced in treatment calves compared with control calves. Serum concentrations of alkaline phosphatase were greater in calves fed the treatment, consistent with previous reports that also showed increases in hip width change (Hill et al., 2007a,b,c). Watkins et al. $(2000,2001)$ has reported greater synthesis of bone growth and serum concentrations of alkaline phosphatase from feeding linolenic acid. Serum concentrations 
Table 8. Initial serum protein and serum constituents pre- and postvaccination on d 6 and change in calves fed milk replacers with and without NeoTec4 fatty acids (Provimi North America, Brookville, OH) in trial 2

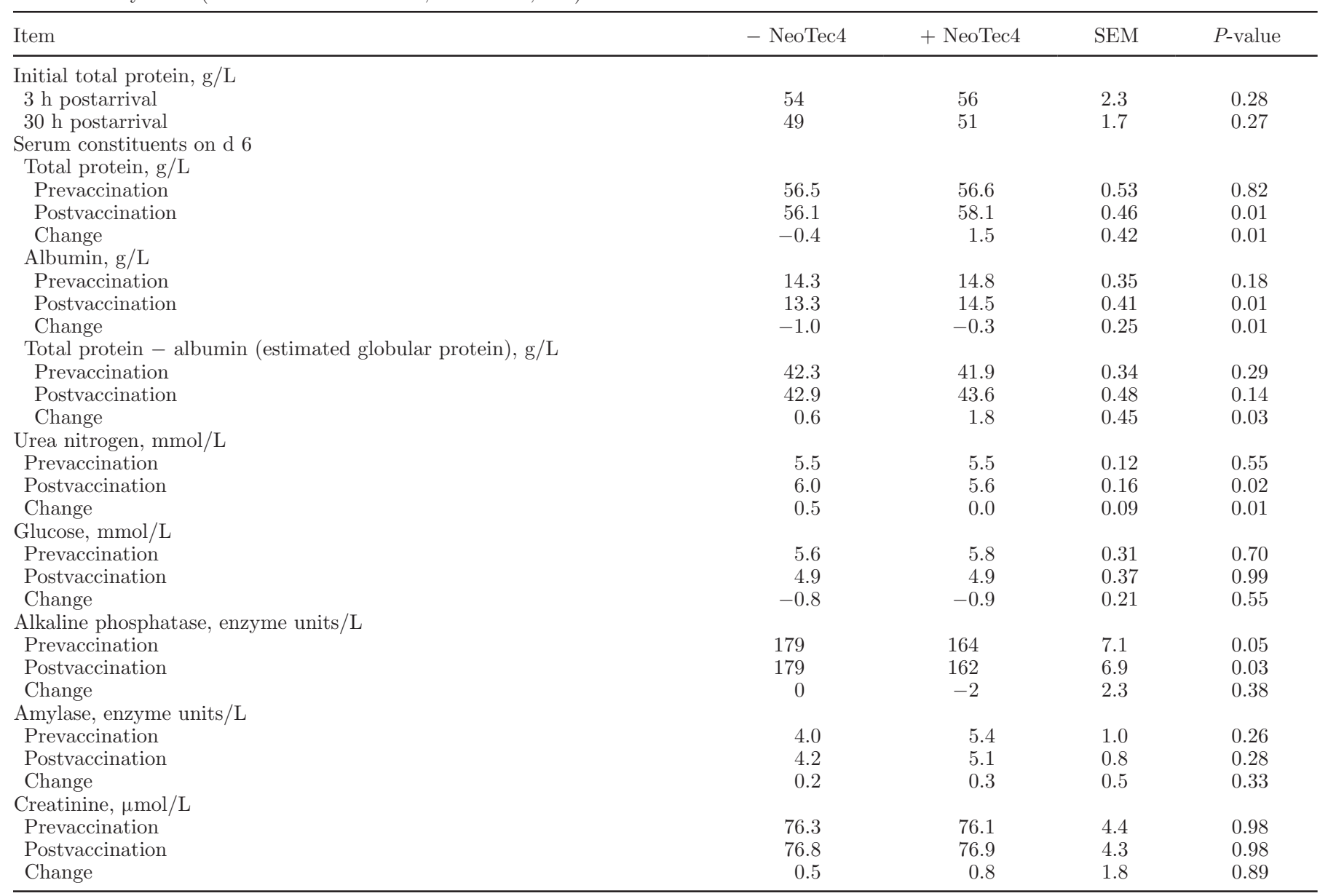

of amylase were greater in calves fed the treatment, consistent with previous reports (Hill et al., 2007a,b,c), and could be the result of butyrate stimulating pancreas development as reported by Kato et al. (1989). These results are consistent with our overall hypothesis that supplementation of MR with NeoTec4 would improve growth and feed efficiency and alter immune responses of calves.

In both trials, treatment resulted in an altered response to a vaccination challenge. Whereas the mRNA abundance for the proinflammatory cytokine TNF $\alpha$ increased in response to a vaccination or toxoid challenge in control calves, it decreased in calves fed the treatment and was significantly different from controls in both trials. Consistent with this, hyperthermia, hypophagia, and lethargy (indicated by incomplete consumption of MR) following vaccination were significantly less in calves fed the treatment than in controls, again providing evidence for altered inflammatory response, although this was only examined in trial 1a. Changes in IL-4 mRNA expression also suggest that the treatment may have an effect on humoral immune responses of calves. This assertion is based on the fact that IL-4 is capable of promoting the growth, survival, and differentiation of $\mathrm{B}$ and $\mathrm{T}$ cells involved in immunoglobulin synthesis (Brown, 2008). Thus, the greater increase in IL-4 mRNA abundance after vaccination challenge in calves fed the treatment compared with control calves may suggest greater potential to enhance antibody responses. In heat-stressed dairy cows, mitogen-induced lymphocyte proliferation and antibody production were greater when cows were fed flaxseed compared with fish oil or the control with no oil (Caroprese et al., 2009). These changes in IL-4 are consistent with the greater titers for BVD and PI3 observed in calves fed the treatment compared with controls, as well as the decreased abnormal fecal days and medical treatments for clostridium sickness with feeding the treatment. In both trials, control calves exhibited decreases in serum total protein and albumin following vaccination, and these decreases were tempered by treatment. In both trials, the treatment prevented the increase in BUN 
Table 9. Relative mRNA abundance of proinflammatory cytokines ${ }^{1}$ pre- and postvaccination on d 6 and change in calves fed milk replacers with and without NeoTec4 fatty acids (Provimi North America, Brookville, $\mathrm{OH})$ in trial 2

\begin{tabular}{|c|c|c|c|c|}
\hline Item & - NeoTec4 & + NeoTec4 & SEM & $P$-value \\
\hline \multicolumn{5}{|c|}{ Tumor necrosis factor- $\alpha$} \\
\hline Prevaccination & 1.23 & 1.73 & 0.43 & 0.18 \\
\hline Postvaccination & 2.31 & 1.54 & 0.34 & 0.06 \\
\hline Change & 1.08 & -0.19 & 0.40 & 0.01 \\
\hline \multicolumn{5}{|l|}{ IL-4 } \\
\hline Prevaccination & 1.08 & 0.95 & 0.30 & 0.51 \\
\hline Postvaccination & 2.23 & 2.95 & 0.22 & 0.13 \\
\hline Change & 1.15 & 2.00 & 0.24 & 0.03 \\
\hline \multicolumn{5}{|l|}{ IL-6 } \\
\hline Prevaccination & 1.30 & 1.91 & 0.47 & 0.14 \\
\hline Postvaccination & 2.73 & 2.11 & 0.37 & 0.79 \\
\hline Change & 1.43 & 0.20 & 0.61 & 0.19 \\
\hline \multicolumn{5}{|l|}{ IL-10 } \\
\hline Prevaccination & 1.12 & 1.60 & 0.43 & 0.43 \\
\hline Postvaccination & 1.71 & 1.41 & 0.24 & 0.48 \\
\hline Change & 0.59 & -0.19 & 0.55 & 0.35 \\
\hline
\end{tabular}

${ }^{1}$ Data are reported in $2^{-\Delta \Delta \mathrm{Ct}}$ form with prevaccinated calves without NeoTec4 as the reference expression point.

following vaccination, suggesting that the treatment prevented the catabolic response to a disease challenge in calves. Not all of our measures were consistent with altered immune responses, as no changes were observed for IL-6 and IL-10 with the treatment. Taken together, however, our data provide evidence that the treatment alters some immune responses and the ability of calves to handle their enteric challenges, which may partly explain the improved growth rate and feed efficiency of calves fed the treatment. Additionally, changes in the immune response indicators occurred within as little as $6 \mathrm{~d}$ of feeding the treatment.

The response we observed is similar to reports in feeder steers fed flaxseed (high in linolenic acid), where the increase in both $\mathrm{TNF} \alpha$ and rectal temperature postLPS challenge was lessened with flaxseed compared with feeding a similar amount of animal fat or fish oil (Farran et al., 2008). Zhao et al. (2007) reported TNFo to be lower in mononuclear cells of hypercholesterolemic patients consuming linolenic acid compared with linoleic acid or arachidonic acid. Similar dampening of TNFo was reported in human monocytes cultured with butyrate in vitro and challenged with Staphylococcus aureus (Saeman et al., 2000). Saeman et al. (2000) also reported that IL-4 and IL-10 increase in human monocytes incubated in vitro with butyrate and challenged with Staphylococcus aureus compared with control cultures.

In our studies, we observed similar results in trials 1a and 2 of improved ADG, reduced scours, reduced treatments for clostridium sickness, and alterations in some immune and inflammatory responses, including blood and serum concentrations of $\mathrm{TNF} \alpha$, IL-4, albu- min, urea nitrogen, globular protein estimates, titers of BVD and PI3, hyperthermia, hypophagia, and lethargy to the fatty acids in the treatment. In trial 1a, the control MR was completely based on animal fat, but in trial 2, the control MR was a mixture of fats. A notable response was an increase in ADG and feed efficiency from feeding treatment fatty acids in the starter during d 84 to 112 (trial 1b) after the treatment fatty acids not being in the starter from d 56 to 84 (trial 1a), when performance did not differ between treatment groups. Further work is needed to elucidate the mechanisms and optimal dosages of each fatty acid for promoting calf health and productivity.

\section{CONCLUSIONS}

Data from this study provide further evidence that feeding the fatty acids in NeoTec4 improves the growth rate and feed efficiency and reduces the incidence of scours and clostridium sickness of young calves. We also conclude that supplementation of MR with NeoTec4 alters some immune and inflammatory responses of young calves following vaccination, which may affect their ability to handle a disease challenge and perhaps explains why scours and clostridium sickness were decreased. This immune response occurred in as few as 6 d of feeding NeoTec4.

\section{ACKNOWLEDGMENTS}

This study was partially funded by Milk Specialties Global Animal Nutrition (Carpentersville, IL). We appreciate the advice and review of the manuscript by 
Jud Heinrichs (Penn State University, University Park) and Al Kertz and Jim Loften from Milk Specialties Global Animal Nutrition.

\section{REFERENCES}

AOAC. 2000. Official Methods of Analysis. Vol. I. 17th ed. Association of Official Analytical Chemists, Arlington, VA.

Ballou, M. A., and E. J. DePeters. 2008. Supplementing milk replacer with omega-3 fatty acids from fish oil on immunocompetence and health of Jersey calves. J. Dairy Sci. 91:3488-3500.

Brown, M. A. 2008. IL-4 production by T cells: You need a little to get a lot. J. Immunol. 181:2941-2942.

Caroprese, M., A. Marzano, G. Entrican, S. Wattegedera, M. Albenzio, and A. Sevi. 2009. Immune response of cows fed polyunsaturated fatty acids under high ambient temperatures. J. Dairy Sci. 92:2796-2803.

Curtis, C. L., C. E. Hughes, C. R. Flannery, C. B. Little, J. L. Harwood, and B. Caterson. 2000. n-3 fatty acids specifically modulate catabolic factors involved in articular cartilage degradation. J. Biol. Chem. 275:721-724.

Farran, T. B., C. D. Reinhardt, D. A. Blasi, J. E. Minton, T. H. Elsasser, J. J. Higgins, and J. S. Drouillard. 2008. Source of dietary lipid may modify the immune response in stressed feeder cattle. J. Anim. Sci. 86:1382-1394.

FASS. 1999. Guide for the Care and Use of Agricultural Animals in Agricultural Research and Teaching. 1st rev. ed. Federation of Animal Science Societies, Savoy, IL.

Fokkink, W. B., T. M. Hill, H. G. Bateman II, J. M. Aldrich, and R. L. Schlotterbeck. 2009. Selenium yeast for dairy calf feeds. Anim. Feed Sci. Technol. 153:228-235.

Guilloteau, P., V. Rome, L. Le Normand, G. Savary, and R. Zabielski. 2004. Is Na-butyrate a growth factor in the preruminant calf? Preliminary results. J. Anim. Feed Sci. 13(Suppl. 1):393-396.

Guilloteau, P., R. Zabielski, J. C. David, J. W. Blum, J. A. Morisset, M. Biernat, J. Woliński, D. Laubitz, and Y. Hamon. 2009. Sodiumbutyrate as a growth promoter in milk replacer formula for young calves. J. Dairy Sci. 92:1038-1049.

Hill, T. M., J. M. Aldrich, R. L. Schlotterbeck, and H. G. Bateman II.. 2007a. Effects of changing the fat and fatty acid composition of milk replacers fed to neonatal calves. Prof. Anim. Sci. 23:135-143.

Hill, T. M., J. M. Aldrich, R. L. Schlotterbeck, and H. G. Bateman II. 2007b. Amino acids, fatty acids, and fat sources for calf milk replacers. Prof. Anim. Sci. 23:401-408.

Hill, T. M., J. M. Aldrich, R. L. Schlotterbeck, and H. G. Bateman II. 2007c. Effects of changing the fatty acid composition of calf starters. Prof. Anim. Sci. 23:665-671.

Hill, T. M., H. G. Bateman II, J. M. Aldrich, and R. L. Schlotterbeck. 2009. Effects of changing the essential and functional fatty acid intake of dairy calves. J. Dairy Sci. 92:670-676.

Hristov, A. N., M. Ivan, and T. A. McAllister. 2004. In vitro effects of individual fatty acids on protozoal numbers and on fermentation products in ruminal fluid from cattle fed a high concentrate, barley-based diet. J. Anim. Sci. 82:2693-2704.

Hu, F. B., M. J. Stampfer, J. E. Manson, E. B. Rimm, A. Wolk, G. A Colditz, C. H. Hennekens, and W. C. Willett. 1999. Dietary intake of a-linolenic acid and risk of fatal ischemic heart disease among women. Am. J. Clin. Nutr. 69:890-897.

Kato, S., N. Asakawa, H. Mineo, and J. Ushijima. 1989. Effect of short-chain fatty acids on pancreatic exocrine secretion in calves aged 2 weeks and 13 weeks. Jpn. J. Vet. Sci. 51:123-127.
Kertz, A. F., and H. Chester-Jones. 2004. Invited review: Guidelines for measuring and reporting calf and heifer experimental data. J. Dairy Sci. 87:3577-3580.

Kim, Y. O., S. A. Yoon, Y. M. Ku, C. W. Yang, Y. S. Kim, S. Y. Kim, E. J. Choi, Y. S. Chang, and B. K. Bang. 2003. Serum albumin level correlates with disease severity in patients with hemorrhagic fever with renal syndrome. J. Korean Med. Sci. 18:696-700.

Liou, Y. A., D. J. King, D. Zibrik, and S. M. Innis. 2007. Decreasing linoleic acid with constant a-linolenic acid in dietary fats increases (n-3) eicosapentaenoic acid in plasma phospholipids in healthy men. J. Nutr. 137:945-952.

Livak, K. J., and T. D. Schmittgen. 2001. Analysis of relative gene expression data using real-time quantitative PCR and the 2(-Delta Delta C(T)) method. Methods 25:402-408.

Merchant, A. T., G. C. Curhan, E. B. Rimm, W. C. Willett, and W. W. Fawzi. 2005. Intake of $n \_6$ and $n \_3$ fatty acids and fish and risk of community acquired pneumonia in US men. Am. J. Clin. Nutr. 82:668-674.

Merck Veterinary Manual. 2008. Hepatic Disease in Large Animals: Introduction. Accessed September 16, 2010. http://www.merckvetmanual.com $/ \mathrm{mvm} /$ index.jsp?cfile=htm/bc/22800.htm.

Orhue, N. E. J., E. A. C. Nwanze, and A. Okafor. 2005. Serum total protein, albumin and globulin levels in Trypanosoma brucei-infected rabbits: Effect of orally administered Scoparia dulcis. Afr. J. Biotechnol. 4:1152-1155.

Orr, C., D. P. Hutcheson, and G. B. Thompson. 1988. Nitrogen kinetics of infectious bovine rhinotracheitis-stress calves. J. Anim. Sci 66:1982-1989.

Robertson, J. B., and P. J. Van Soest. 1981. The Detergent System of Analysis and its Application to Human Foods. Cornell University, Ithaca, NY

Saeman, M. D., G. A. Böhmig, C. H. Österreicher, H. Burtscher, O. Parolini, C. Diakos, J. Stöckl, W. H. Hörl, and G. J. Zlabinger 2000. Anti-inflammatory effects of sodium butyrate on human monocytes: Potent inhibition of IL-12 and up-regulation of IL-10 production. FASEB J. 14:2380-2382. doi:10.1096/fj.00-0359fje.

Sander, E. G., R. G. Warner, H. N. Harrison, and J. K. Loosli. 1959. The stimulatory effect of sodium butyrate and sodium propionate on the development of rumen mucosa in the young calf. J. Dairy Sci. $42: 1600-1605$

USDA. 2007. Dairy 2007 Part I: Reference of Dairy Cattle Health and Management Practices in the United States, \#N480.1007. USDAAPHIS-VS CEAH, Fort Collins, CO.

Van Soest, P. J., J. B. Robertson, and B. A. Lewis. 1991. Methods for dietary fiber, neutral detergent fiber, non-starch polysaccharides in relation to animal nutrition. J. Dairy Sci. 74:3583-3597.

Watkins, B. A., Y. Li, K. G. Allen, W. E. Hoffmann, and M. F Seifert. 2000. Dietary ratio of $(n-6) /(n-3)$ polyunsaturated fatty acids alters the fatty acid composition of bone compartments and biomarkers of bone formation in rats. J. Nutr. 130:2274-2284.

Watkins, B. A., H. E. Lippman, L. Le Bouteiller, Y. Li, and M. F. Seifert. 2001. Bioactive fatty acids: Role in bone biology and bone cell function. Prog. Lipid Res. 40:125-148.

Wildman, E. E., G. M. Jones, P. E. Wagner, R. L. Bowman, H. F Troutt Jr., and T. N. Lesch. 1982. A dairy cow body condition scoring system and its relationship to selected production characteristics. J. Dairy Sci. 65:495-501.

Zhao, G., T. D. Etherton, K. R. Martin, P. J. Gillies, S. G. West and P. M. Kris-Etherton. 2007. Dietary $\alpha$-linolenic acid inhibits proinflammatory cytokine production by peripheral blood mononuclear cells in hypercholesterolemic subjects. Am. J. Clin. Nutr. 85:385-391. 